Preliminary communication

https://doi.org/10.32903/zs.66.1.6

UDK 37.035.2-057.87

\title{
PEDAGOGY WORKSHOPS FOR PROMOTING PROSOCIAL BEHAVIOUR AMONG STUDENTS - CASE STUDY
}

\author{
Dajana Bičanić \\ Elementary school Ljudevit Gaj, Osijek, Croatia, \\ Maja Brust Nemet \\ Faculty of Education, Josip Juraj Strossmayer University in Osijek, Croatia,
}

\begin{abstract}
Prosocial behaviour refers to intentional behaviour aimed at helping others or having a positive influence on others. A community to which a child belongs plays a great role in developing prosocial behaviour. Therefore, great attention should be about the development of the prosocial behaviour in the classroom, which will fully contribute to the student's empathy development, active listening skills, being able to work collaboratively, being able to resolve conflict constructively and self-esteem development as well as self-confidence development. Pedagogical workshops can contribute to a better understanding of a child's personality. According to that, their focus is on the actual process whose purpose is to provide each participant with the feeling of equality and belonging.

The aim of this paper was to investigate whether pedagogical workshops encourage prosocial behaviour in students. The study was conducted during March 2019 and included methodological triangulation (participatory observation, sociometric test and interview) among students of one class departments in a rural area of Slavonia, Croatia. The results of the qualitative research showed that pedagogical workshops provide the conditions necessary to encourage prosocial behaviour in students. Also, the research showed that pedagogical workshops are related to the strengthening of social relations within the group and that certain activities are related to the student's development of empathy, self-confidence and constructive conflict resolution.
\end{abstract}

Key words: prosocial behaviour, pedagogical workshops, social competence

\section{INTRODUCTION}

Prosocial behaviour is a moral behaviour that manifests itself in helping others, cooperating, sharing with others, showing empathy and understanding for others, and it needs to be encouraged from an early age through functional and intentional upbringing. Each student is unique, has different interests, desires, needs, opinions, expectations, skills and abilities, so it is understandable that sometimes there are situations where a student's individual characteristics are conflicted with others, so it is necessary to continuously encourage prosocial behaviour. The ultimate goal was to achieve a positive classroom atmosphere and socially competent students. By actively participating in pedagogical workshops, students develop the skills of active listening, cooperation, empathy, constructive conflict resolution, and self-confidence and self-esteem. A stimulating classroom atmosphere enables students to achieve personal satisfaction and a sense of belonging in which there is no lack of trust, support, understanding, patience and help. 
THEORETICAL AND PRACTICAL PROBLEMS AND DISCUSSIONS

\section{THE DEVELOPMENT OF PROSOCIAL BEHAVIOUR THROUGH PEER INTERACTION}

Prosocial behaviour is defined as intentional behaviour with positive consequences for other people. Prosocial behaviour includes benevolence, kindness, material assistance, moral support, empathy, and altruism (Eisenberg and Miller, 1987). Apart from hereditary factors, the culture to which a child belongs also plays an important role in prosocial behaviour. The important factors that condition the existence of prosocial behaviour are related to cognitive and moral development, and especially to the development of empathy (Brajša-Žganec, 2003). Prosocial behaviour is certainly an indicator of children's competent behaviour and good socioemotional functioning (Brajša-Žganec, 2003: 49). The community is of essential value for children's social and emotional development (Katz and McClellan, 1997). In addition to family, which as the primary social community most strongly influences the child's functioning, by becoming a part of a peer group, the child satisfies the need for intimacy, forms an image of one, acquires social skills, and learns to help, share and cooperate (Klarin, 2006). In schools with a positive culture, teachers should encourage positive social relationships, develop social skills, manage conflicts, ensure the safety of students, support healthy working conditions and improve the schooling conditions of students (Jurčić, 2012). Encouraging the prosocial behaviour, we encourage the interaction with the community; at the level of class, school, family and local community and the social competence of students develops as a consequence (Opić, 2010). In the age of digitalization, the school system has an even greater responsibility for enriching the curriculum with activities aimed at prosocial behaviour of students (Kholiq and Solehuddin, 2020).

According to the humanist approach in education, the goal of education is not only the acquisition of knowledge, but also the complete development of the individual, while respecting his interests and needs, where intellectual and emotional features of development such as self-awareness, research and awareness of one's emotions and motives stand out, as well as social communication skills and prosocial behaviour, and the development of satisfaction and pride (Brust Nemet, 2015). Peer interactions contribute to collaborative learning structure, leadership skills, impulse control, aggression and hostility, the development of prosocial behaviour, provide emotional security, love, affection, intimacy, solidarity and form the basis of all the relationships. The pedagogical and social implications of peer relations are woven into the micro-pedagogical and social structure of the institution (Buljubašić-Kuzmanović, 2010). Prosocial behaviour can have positive effects on improving the cognitive performance and strengthening interpersonal relationships and neural coordination (Balconi and Fronda, 2020). Goleman (1997), the originator of socio-emotional learning (SEL), developed an approach to education aimed at teaching children how to integrate their own cognitive abilities, emotions and behaviour and enable children to develop and apply socio-emotional skills and thus acquire socioemotional competence. Research has shown that socially and emotionally competent individuals most often have high academic and professional achievements, actively contribute to the development of their immediate and wider community and represent a role model in private and social life. They know how to recognize their strengths, set realistic goals and plan to achieve them with optimism. They are able to successfully solve problems, respect the opinions of other people and establish quality relationships with others. The goal of SEL is to promote and encourage the development of these competencies, precisely through education. SEL is based on empirical data derived from research on social competence as well as knowledge in the field of developmental psychology and pedagogy. Through the SEL approach, a supportive and safe learning environment is formed in which students feel accepted and in which their opinions are valued. In such an environment, they are intrinsically motivated to acquire knowledge, social and cognitive skills, prosocial attitudes that contribute to better academic achievement, and prosocial behaviour (Goleman, 1997). Numerous studies (Marzano et al., 2003, Battistich et al., 1997, Solomon et al., 2000, 1997, according to Jennings and Greenberg, 2009) 
Dajana Bičanić, Maja Brust Nemet PEDAGOGY WORKSHOPS FOR PROMOTING PROSOCIAL

have proven the positive impact of creating prosocial classes, but the assumption of creating prosocial classes is socio-pedagogical teacher competence to be able to encourage prosocial behaviour, collaborative learning, promote extrinsic goals, control the learning climate, encourage student activity, and co-create classroom and school culture (Brust Nemet, 2018). Using meta-analysis, Baranović (2006) states positive effects such as fewer absences, better grade point average and better performance on final tests with the application of SEL programs in American schools, while in Croatian schools the social and emotional area is less represented and socio-emotional content in current curricula need to be increased. It is to be expected that by developing self-control, problem-solving and social skills, students will be better prepared for learning and cognitive engagement.

\section{Pedagogical WORKSHOPS IN THE FUNCTION OF PROSOCIAL BEHAVIOUR}

According to the National Framework Curriculum for Preschool and General Compulsory and Secondary Education (2011), student-centred education is promoted, which includes, among other things, the creation of a pleasant educational, classroom and school atmosphere that will encourage students' interest and motivation, as well as provide a sense of security and mutual respect. Teachers are expected to consciously and systematically contribute to students' socialization (Jurčić, 2012), i.e. prepare and lead pedagogical workshops that create teaching situations that encourage the development of social competencies, and prevent behavioural problems, as well as favour the development of prosocial behaviour of students. Pedagogical workshops are based on experiential, holistic and social learning (Buljubašić-Kuzmanović and Vilić-Kolobarić, 2003), which is process-oriented and not outcome-oriented. The role of teachers is to facilitate and encourage the exchange of children's experiences because pedagogical workshops, as a specific form of group interaction, enable experiential learning not only about oneself but also about others and the world (Bognar, Uzelac and Bagić, 2000). Pedagogical workshops enable the participants of the teaching process to express their wishes, needs, and feelings freely. Everyone has the opportunity to talk about what he is interested in and what matters to them, while the other listeners develop curiosity and encourage them to hear and learn more. Working in the pedagogical workshops has elements of everyday life and informal learning and is therefore particularly valuable. In addition to circular communication, the thing that works in pedagogy workshops is a pleasant and democratic climate, humour, expressing oneself and understanding other people's emotions, and exchanging opinions and experiences. The thing that makes pedagogical workshops different from the regular school programs is that they are not focused on acquiring knowledge and remembering the facts (Dubovicki and Budić, 2019). In order to develop prosocial behaviour in students with the help of pedagogical workshops, teachers should continuously conduct activities aimed at creating a positive image of oneself, developing self-esteem and self-confidence, empathy, active listening and encourage students to constructively resolve conflicts through which students will strengthen social competence.

\section{Methods}

The aim of the research is to determine whether pedagogical workshops encourage students' prosocial behaviour. From the aim of the research, the following research questions were formed:

RQ1: What is the social status of 1st grade students before and after conducting pedagogical workshops? 
RQ2: How do pedagogical workshops contribute to strengthening social relations within the group?

RQ3: Why do certain pedagogical activities in pedagogical workshops encourage prosocial behaviour in students?

The research sample is random, and it consisted of students from a 1st grade department $(\mathrm{N}=$ 15) of a Slavonian primary school in the rural area in the Republic of Croatia.

\section{RESEARCH INSTRUMENTS AND PROCEDURE}

An evaluation case study was chosen because its goal is to describe, explain, and evaluate a case, and is often conducted for the purpose of evaluating a program or project based on analytical generalization (Yin, 2007). The case study included participatory observation of students in one class, a sociometric test, and an interview. Prior to conducting the research, parents signed a consent form for their children to participate in the research process. Students were introduced to the research and had the opportunity to drop out during the research. Research results may only be used for research purposes with guaranteed anonymity of the respondents. The sociometric test was conducted at the beginning (initial state) and at the end (final state) of the case study, while the participating observation and interview were conducted during March 2019. The case study included determining the sociometric status of students before and after the implementation of four pedagogical workshops to determine the initial state, the effect of factors and the final state, as well as participating observation of students in one class during active participation in four pedagogical workshops. The aim was to find out how and why pedagogical workshops contribute to strengthening the social relations of the group, and strengthen the prosocial behaviour of students. The initial and final state was measured by a sociometric test, while after each cycle (conducted pedagogical workshops) the effect of each workshop was measured as the 1st, 2 nd, 3rd and 4th factors. The difference in efficiency was determined separately for each cycle and this result was generalized to the base set. All pedagogical workshops consisted of activities whose main goal was to develop students' self-confidence, ability to non-violent communication, active listening skills and to develop empathy and skills of constructive conflict resolution. In order to determine the sociometric status in the classroom before and after the participating in pedagogical workshops, a sociometric survey was conducted. Sociometry is a research technique that deals with measuring and researching the social status of an individual within a group. The goal of using sociometry is to act in accordance with the results and to improve relations within one class department. The sociometric procedure is based on two main relationships between individuals: choice and rejection. Keeping that in mind, the students answered four questions, in writing: With who would you like to sit the most? (Positive). With who would you not like to sit? (Negative). With who would you like to play the most? (Positive). With who would you not like to play? (Negative). The data were eventually processed in the programme Sociometrics.com. The structured interview was composed of the same questions and was conducted after each pedagogical workshop, i.e. after each cycle, and it contained questions about the degree of liking of each workshop (excellent, good, bad).

\section{RESEARCH RESULTS AND IMPLEMENTATION}

Comparing the initial and final nomination diagram (Figure 1), which shows the relationship of positive and negative preferences to the person with who they would or would not like to sit, it is evident that there are changes. The first nomination table shows that there 
are 3 popular students, while the second shows that there are 4 popular students. Also, the first table shows 4 neglected students while the second table does not show any neglected students. Although the first table shows that there are 2 rejected students, and the second even 4, we should not ignore the fact that the student TP answered on a repeated sociometric questionnaire that she would like to sit with everyone, which greatly affects the obtained results. Accordingly, students DK, IH and MM would not be rejected.
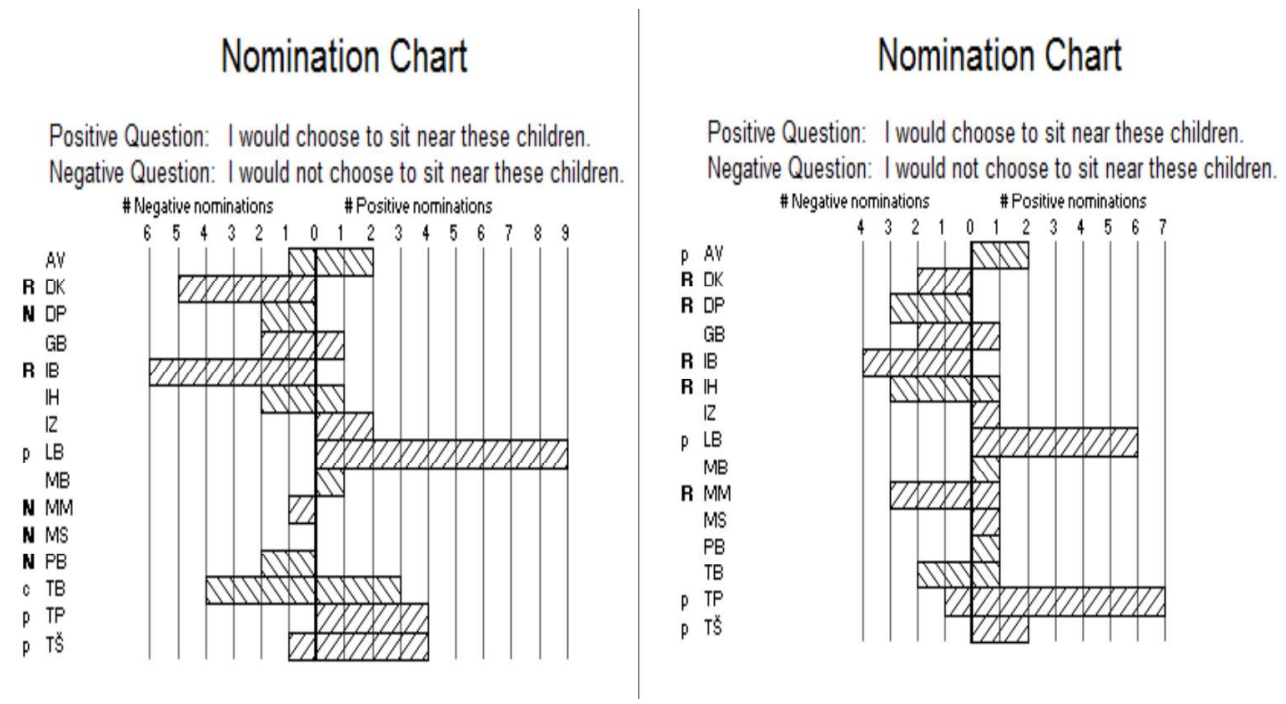

Figure 1 The comparison of the nomination diagrams

(With who would you like to sit? With who would you not like to sit?)

Comparing the initial and final nomination diagram (Figure 2), which shows the relationship of positive and negative preferences to the person with who they would like to or not play with, it is evident that there are positive changes. Namely, on the first diagram it can be noticed that there are 4 popular students while on the second one it can be noticed that there are 3 popular students. However, as in the previous comparison, special attention should be paid to the fact that as many as three students answered in a repeated sociometric questionnaire that they would like to play with everyone. So, with that, each student gets three more positive votes. The first table shows that there are 5 rejected students, while the second shows that there are 3 rejected students. Consistent with the fact that three students gave everyone a positive vote, students IB and PB who are shown rejected on the second table, having three positive votes added, would not be rejected. Also, students who are shown to be neglected in the second table, if three additional positive votes are added to each of them, cease to be ignored. 
Nomination Chart

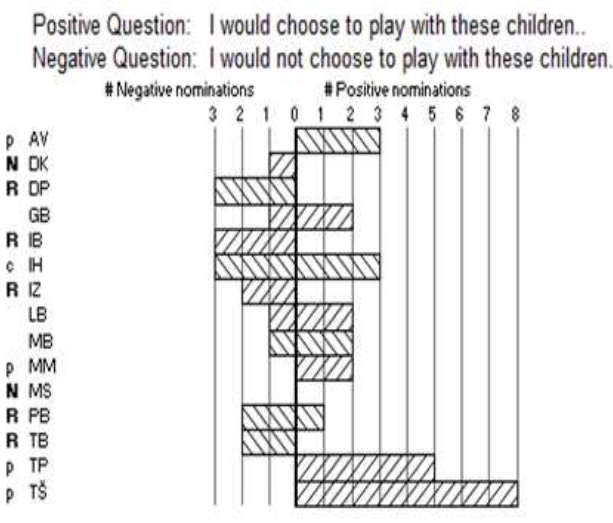

\section{Nomination Chart}

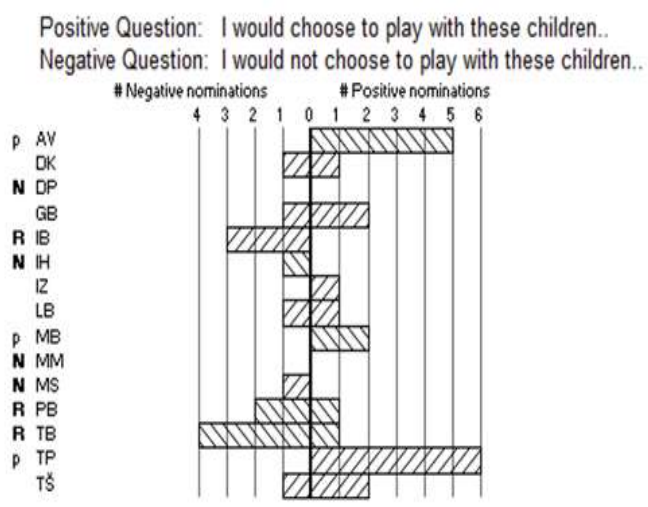

Figure 2 The comparison of the nomination diagrams

(With who would you like to play the most? With who would you not like to play?)

During the period of one month, four pedagogical workshops were held on the topic "You fit in very well", "Snake and giraffe speech", "Active listening" and "Don't make fun of me", and after each pedagogical workshop, students expressed their own feelings.

The goal of the first pedagogical workshop "You fit in very well" was to develop a positive image of oneself, a sense of self-worth, and to notice the positive qualities of others and the development of collaborative relationships in the group. The workshop consisted of four activities: "Ball of yarn", "How others see me" and "You fit in very well". This workshop had a very positive impact on the students (13 out of 15 students said they felt great). During this workshop, students thought about other people's positive traits and gained insight into what others think of them, which influenced the development of a positive image of themselves. Students gained a sense of acceptance and a sense of belonging to the class. Several times after the workshop, the students used to ask about when they would sing the song "Pretty name" again and they said that they would sing that song at home to their brothers and sisters. Also, during their stay in their own classroom, it was noticed that the students looked at the puzzle on the board several times during the break and talked about the characteristics of each of them.

The second pedagogical workshop "Snake and Giraffe Speech" had a very positive effect on the students (15 out of 15 students felt great). The students took the giraffe speech very seriously and used it often in the time that followed the workshop. Also, in situations where a student would use snake speech, other students would correct him and said that he should be a "giraffe" and express himself in giraffe (me) speech and they would show him how to do so.

Through the third pedagogical workshop "Active Listening", students gained insight into what active listening is and how it can be implemented. However, in order to develop full competence in active listening, it has been observed that more than just one workshop is needed. It was observed that several students still, at some points, did not show active listening skills. After the workshops, there were still situations in which they would not actively listen to the interlocutor. All students responded positively in the interview and said they felt great.

The fourth pedagogical workshop "Don't make fun of me" was also liked by all students (15 out of 15 felt great). The workshop encouraged reflection on understanding and tolerance towards members of different groups, developing empathy, devising ideas to address discrimination in the classroom and encourage self-confidence. 
Dajana Bičanić, Maja Brust Nemet PEDAGOGY WORKSHOPS FOR PROMOTING PROSOCIAL..

\section{Discussion}

Based on the methodological triangulation, it can be established that pedagogical workshops had a positive effect on students, encouraged them to think about desirable behaviour in the classroom and thus encourage prosocial behaviour of students. The results of the study (Santos and Langill, 2020), after the experiment among 98 students, showed that the prosocial behaviour, care for others, emotional skills and levels of relaxation significantly improved in the experimental group that participated in relaxation activities, compared to the control group, which indicates that implementing activities to develop prosocial behaviour in the curriculum can facilitate the development of social and emotional skills in students. As well as the longitudinal study (Chen, Tian and Huebner, 2020) with results suggesting the importance of comprehensive socio-emotional interventions to promote positive student development and student prosocial behaviour.

Based on the research results, it has been determined that students as early as the 1st grade form opinions about other people and are aware of the fact who they like or who they do not like. This has been confirmed by the results of the sociometric test because the social status of students before and after the pedagogical workshops changed in a positive direction. Research results (Simon, 2020) show that the relationships formed in school are most strongly associated with self-esteem and self-confidence that have direct effects on prosocial behaviour. It was noticed that the repeated sociometric test changed the preferences and attitudes of the students. Pedagogical workshops contributed to the strengthening of social relations within the group. However, in order to talk about the realization of prosocial behaviour in full, it is necessary to continuously conduct pedagogical workshops and thus influence the prosocial behaviour of students. Binfet (2020) states that it is necessary to implement social and emotional learning in curricula through various activities such as activities in which students will acquire the skills of kindness and goodness.

The activities that the students especially remembered and that had the greatest impact on the positive changes were "Pretty name", "Snake and giraffe speech" and "Ugly duckling". In the "Pretty Name" activity, students felt important, which influenced their positive selfimage and self-confidence. The activity "Snake and Giraffe Speech" is an activity that students often talked about with each other. When there was a conflict in the classroom, students would stop on their own initiative, think about their behaviour, the behaviour of others, and the best way to resolve the conflict. If a student showed signs of snake speech, others would immediately warn him that he should be a giraffe. Accordingly, the "Ugly Duckling" activity has also greatly influenced the positive changes. It helped developed empathy and encouraged students to think about their own actions. Based on the research results, Baumsteiger (2019) concludes that integrative interventions to encourage prosocial behaviour, such as watching videos, provoking prosocial behaviour, and reflecting on how those behaviours relate to one's values, improve prosocial behaviours and promote prosocial habits.

Research has shown that pedagogical workshops provide the conditions needed to encourage prosocial behaviour in students. With the help of pedagogical workshops, the teacher creates the preconditions for the emotional, cognitive and social development of students and thus prevents possible difficulties in behaviour and functioning within the classroom (Janković, 1996). In pedagogical workshops, the emphasis is on establishing collaborative relationships within the group and on creating a friendly atmosphere. Research showed that pedagogical workshops influence the strengthening of social relations within the group and that certain activities greatly influenced the student's development of empathy, self-confidence and constructive conflict resolution.

Given that research participants were students of only one 1st grade, in the future research it is necessary to expand the sample and conduct longitudinal research that will measure 
the impact of pedagogical workshops as a function of encouraging prosocial behaviour in students.

\section{ConcLusion}

Prosocial behaviour is a characteristic of intentional behaviour that bases its purpose on the well-being of other people. It is an essential aspect of moral behaviour that every person should possess. Prosocial behaviour takes root in the context of a community. Therefore, it is possible to influence the prosocial behaviours of students through functional and intentional education. In order to achieve the foundations for prosocial behaviour in students, it is necessary to create a pleasant and stimulating classroom atmosphere and implement pedagogical activities in the school curriculum, for which the teacher is the most responsible.

Research results have significant implications for understanding and promoting prosocial behaviour because they show that pedagogical activities encourage students 'prosocial behaviour. Therefore, every teacher should conduct pedagogical workshops in daily educational work with students at all levels of the educational system. Sociometric research established more harmonious social relations after the active participation of students in pedagogical workshops, with the help of which students developed empathy, strengthened self-confidence and practiced non-violent conflict resolution. Methodological triangulation in the case study determines that pedagogical activities in pedagogical workshops encourage prosocial behaviour in students because the theme and form of implementation are aimed at acquiring prosocial habits of students. Compassion, giraffe or me-speech and non-violent conflict resolution were practiced by students during active participation in pedagogical workshops, while expressing satisfaction with their participation, and awareness of how good it is to do good to yourself and others, so the assumption is that such prosocial behaviours will also occur in extracurricular situations with peers and families.

\section{REFERENCES}

Balconi, M. \& Fronda, G. (2020). The "gift effect" on functional brain connectivity. Inter-brain synchronization when prosocial behaviour is in action. Scientific Reports, 10(1), 1-10. http://dx.doi. org/10.1038/s41598-020-62421-0

Baranović, B. (2006). Društvo znanja i nacionalni kurikulum za obvezno obrazovanje. In Baranović, B. (Ed.) Nacionalni kurikulum za obvezno obrazovanje u Hrvatskoj: različite perspektive. (pp. 837), Zagreb: Institut za društvena istraživanja

Baumsteiger, R. (2019). What the World Needs Now: An Intervention for Promoting Prosocial Behavior. Basic and Applied Social Psychology, 41(4), 215-229. https://doi.org/10.1080/ 01973533.2019.1639507

Binfet, J. T. (2020). Kinder Than We Might Think: How Adolescents Are Kind. Canadian Journal of School Psychology, 35(2), 87-99. https://doi.org/10.1177/0829573519885802

Bognar, L., Uzelac, M. \& Bagić, A. (2000). Budimo prijatelji - 33 pedagoške radionice. Zagreb: Mali korak.

Brajša-Žganec, A. (2003). Dijete i obitelj: emocionalni i socijalni razvoj. Jastrebarsko: Naklada Slap.

Brust Nemet, M. (2015). Socijalno-pedagoške kompetencije učitelja u kurikulumu kulture

suvremene škole (Doktorska disertacija). Zagreb: Filozofski fakultet.

Brust Nemet, M. (2018). A Correlation between Teachers' Social and Pedagogical Competences and School Culture. Sodobna pedagogika/ Journal of Contemporary Educational Studies, 69(3), 142155. 
Buljubašić Kuzmanović (2010). Socijalne kompetencije i vršnjački odnosi u školi. Pedagogijska istraživanja, 2, 191-204.

Buljubašić-Kuzmanović, V. \& Vilić-Kolobarić, K. (2003). Dobar pristup sebi i drugima. Đakovo: Tempo.

Chen, X., Tian, L. \& Huebner, E. S. (2020). Bidirectional Relations Between Subjective Well-Being in School and Prosocial Behavior Among Elementary School-Aged Children: A Longitudinal Study. Child and Youth Care Forum, 49(1), 77-95. doi: http://doi.org/10.1007/s10566-019-09518-4

Dubovicki, S. \& Budić, M. (2019). Intellection of Upbringing in Global Context of Present and Future Challenges in Pedagogy. Jahr, 10(2), 413-425. https://doi.org/10.21860/j.10.2.8

Eisenberg, N. \& Miller, P. A. (1987). The relation of empathy to prosocial and related behaviors. Psychological Bulletin, 101(1), 91-119. https://doi.org/10.1037/0033-2909.101.1.91

Goleman, D. (1997). Emocionalna inteligencija. Zagreb: Mozaik knjiga.

Janković, J. (1996). Pristupanje obitelji. Zagreb: Alinea.

Jennings, P. A. \& Greenberg, M. T. (2009). The Prosocial Classroom: Teacher Social and Emotional Competence in Relation to Student and Classroom Outcomes. Review of Educational Research, 79(1), 491-525.

Jurčić, M. (2012). Pedagoške kompetencije suvremenog učitelja. Zagreb: Recedo.

Katz, L. \& McClellan, D. (1997). Poticanje razvoja dječje socijalne kompetencije. Zagreb: Educa.

Klarin, M. (2006). Razvoj djece u socijalnom kontekstu: roditelji, vršnjaci, učitelji - kontekst razvoja djeteta. Jastrebarsko: Naklada Slap.

Kholiq, A. \& Solehuddin, M. (2020). How to increase the students' prosocial behaviour in the era of technology? International Journal of Information and Education Technology, 10(4), 309-313. http://doi.org/10.18178/ijiet.2020.10.4.1381

Nacionalni okvirni kurikulum za predškolski odgoj i obrazovanje te opće obvezno i srednjoškolsko obrazovanje (2011). Zagreb: Ministarstvo znanosti, obrazovanja i športa Republike Hrvatske.

Opić, S. (2010). A possible programme for the development of social competence of pupils in primary education. Pedagogijska istraživanja, 7(2), 229-229.

Santos, A. \& Langill, C. (2020). MindMasters 2: A 3-Month Pilot Study Evaluating Grade 3 Children's Social and Emotional Skills. Canadian Journal of School Psychology, 35(2), 123-138. https://doi. org/10.1177/0829573519827209

Simon, P. (2020). Enabling relations as determinants of self-satisfaction in the youth: The path from self-satisfaction to prosocial behaviors as explained by strength of inner self. Current Psychology, 39(2), 656-664. https://doi.org/10.1007/s12144-018-9791-0

Yin, R. K. (2007). Studija slučaja - dizajn i metode. Zagreb: Fakultet političkih znanosti Sveučilišta u Zagrebu. 